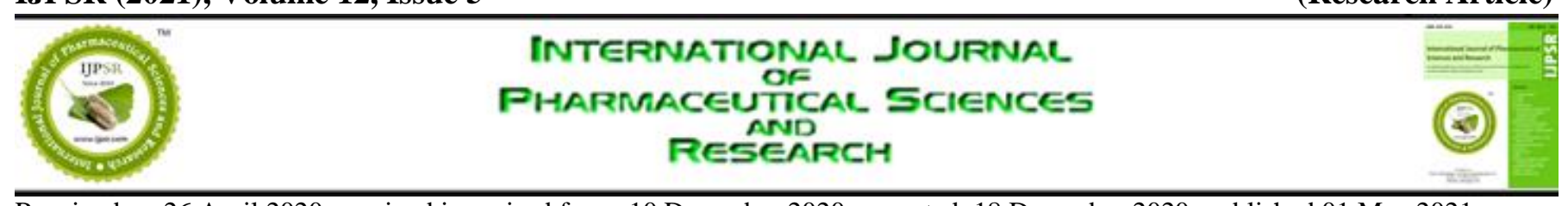

Received on 26 April 2020; received in revised form, 10 December 2020; accepted, 18 December 2020; published 01 May 2021

\title{
DEVELOPMENT AND VALIDATION OF STABILITY INDICATING HPTLC METHOD FOR THE ESTIMATION OF SOFOSBUVIR
}

\author{
M. R. Ghante *, S. D. Sawant, A. Shinde and V. K. Bhusari
}

Sinhgad Technical Education Society's, Smt. Kashibai Navale College of Pharmacy (Kondhwa), Pune 411048, Maharashtra, India.

Keywords:

Method validation, Sofosbuvir, Stability-indicating, HPTLC, ICH guidelines

\section{Correspondence to Author:}

Dr. Minal R. Ghante

Associate Professor,

Sinhgad Technical Education

Society’s, Smt. Kashibai Navale

College of Pharmacy (Kondhwa),

Pune - 411048, Maharashtra, India.

E-mail: mrghante@sinhgad.edu

\begin{abstract}
A simple stability-indicating high-performance thinlayer chromatographic method which is economic, selective, and precise for analysis of Sofosbuvir (SFB), both as a bulk drug and in formulations, was developed and validated according to $\mathrm{ICH}$ guidelines. The method employed HPTLC precoated Merck TLC plates RP-18 $\mathrm{F}_{254}$ as the stationary phase while the solvent system prepared by mixing n-Hexane: Ethyl Acetate: Methanol in proportion 5:3:2 v/v. The system was found to give a compact spot for the drug $\left(R_{\mathrm{f}}\right.$ value of $\left.0.452 \pm 0.004\right)$. Densitometric analysis of SFB was carried out in the absorbance mode at $261 \mathrm{~nm}$. The linear regression analysis data for the calibration plots showed a good linear relationship, $\mathrm{R}^{2}=$ 0.9994 , with respect to peak area in the concentration range 100-600 ng/band. The LOD and LOQ were $8.009 \mathrm{ng} / \mathrm{b}$ and and $24.270 \mathrm{ng} / \mathrm{band}$, respectively. SFB was subjected to hydrolysis, oxidation, and thermal degradation, which indicates the drug is susceptible to hydrolysis, oxidation, and heat. The method was validated for precision, recovery, and robustness. Statistical analysis proves that the method is repeatable, selective, and accurate for the estimation of SFB.
\end{abstract}

INTRODUCTION: Sofosbuvir (SFS) chemically is (S)-isopropyl-2-(S)-(2R, 3R, 4R, 5R)-5-(2, 4 dioxo-3, 4-dihydro pyrimidin-1(2H)-yl)-4-fluoro3hydroxy-4-methyltetrahydrofuran-2-yl)methoxy)phenoxy) phosphorylamino) propionate. Sofosbuvir is a nucleotide analogue used in combination with other drugs for the treatment of hepatitis virus $(\mathrm{HCV})$ infection ${ }^{1-2}$. Literature review revealed few RP-HPLC ${ }^{3-7}$ and UPLC-ESI MS/MS ${ }^{8-9}$ methods for estimation of SFB.

\begin{tabular}{|l|c|}
\hline QUICK RESPONSE CODE & DOI: \\
\hline DOI link: http://dx.doi.org/10.13040/IJPSR.0975-8232.12(5).2656-61 \\
\hline
\end{tabular}

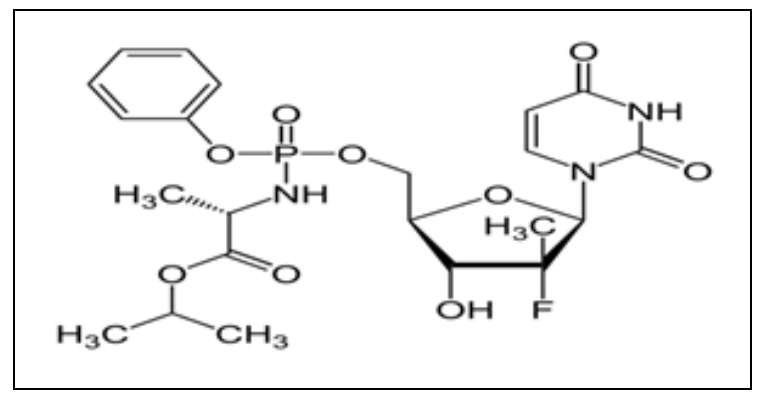

FIG. 1: STRUCTURE OF SOFOSBUVIR

There was no stability-indicating HPTLC method reported. Hence, the purpose of this work was to develop a simple stability-indicating HPTLC method for the determination of SFB in its bulk and pharmaceutical dosage form to provide better scope for further research on the drug. The HPLC method was developed as recommended by $\mathrm{ICH}$ guidelines $10-12$ 


\section{MATERIALS AND METHODS:}

Chemical and Reagents: The reagents used in this work were of AR Grade, Methanol, Toluene, NHexane, Ethyl Acetate, Hydrochloric Acid, Sodium Hydroxide, Hydrogen Peroxide (30\%) purchased from Omkar traders, Mumbai, and double-distilled water from Elga water purification system.

Equipment: The instruments used in the study were Camag HPTLC system comprising of Linomat-5 applicator, Camag TLC Scanner 3, Win CATS software V- 1.4.2, Merck TLC plates RP-18 $\mathrm{F}_{254}$ pre-coated plates, Hamilton syringe $(100 \mu \mathrm{l})$, Shimadzu balance Model AY-120, Hot Air Oven (Kumar Laboratory Oven), Photostability chamber (Make Newtronic, Model IC DAC version 1.2) and calibrated glassware were used for the study.

Selection of Detection Wavelength: From the standard stock solution, further dilutions were done using mobile phase and scanned over the range of 200-400 $\mathrm{nm}$ and the spectrum was obtained. It was observed that Sofosbuvir showed considerable absorbance at $261 \mathrm{~nm}$.

Preparation of Standard Stock Solution: Standard stock solution of SFB was prepared by dissolving $10 \mathrm{mg}$ of drug in $10 \mathrm{ml}$ of methanol to get concentration of $1000 \mu \mathrm{g} / \mathrm{ml}$. From the standard stock solution, $1 \mathrm{ml}$ was further diluted to $10 \mathrm{ml}$ with mobile phase to get $100 \mu \mathrm{g} / \mathrm{ml}$ solution of SFB.

Selection of Mobile Phase and Chromatographic Conditions: Chromatographic separation studies were carried out on the standard working solution of SFB (200ng/band). Initially, trials were carried out using various solvents in various proportions on normal TLC plates, to obtain the desired system suitability parameters. After few trials, n-Hexane: Ethyl Acetate: Methanol (5:3:2 v/v), was chosen as the mobile phase, which gave good resolution and acceptable peak parameters. Other chromatographic conditions like chamber saturation time, run length, sample application volume, sample application positions, the distance between tracks, detection wavelength were optimized to gave reproducible $\mathrm{R}_{\mathrm{f}}$ values and symmetrical peak shape for the drug peak.

Preparation of Mobile Phase: Mobile phase was prepared by mixing n-Hexane: Ethyl Acetate:
Methanol in proportion 5:3:2 v/v. It was then sonicated on an ultrasonic water bath for $15 \mathrm{~min}$.

Preparation of Sample Solution of Tablets (Assay): Twenty tablets [Myhep $400 \mathrm{mg}$ tablets, Mylan, Each film-coated tablet contains $400 \mathrm{mg}$ of sofosbuvir] were weighed and powdered. Tablet powder equivalent to $10 \mathrm{mg}$ of SFB was weighed and transferred to $10 \mathrm{ml}$ volumetric flask and was diluted with methanol. It was sonicated for $15 \mathrm{~min}$ and filtered so as to get a solution having a concentration $1000 \mu \mathrm{g} / \mathrm{ml}$. $1 \mathrm{ml}$ of this solution was further diluted with mobile phase to get the final concentration of $100 \mu \mathrm{g} / \mathrm{ml}$ SFB.

$2 \mu \mathrm{l}$ of this solution was applied on the plate and analyzed. Six determinations were carried out from homogenous sample to determine \% assay.

Stress Degradation Studies of Bulk Drug: Stress degradation studies were carried under condition of acid, base, neutral hydrolysis, oxidation, dry heat and photolysis. For each study, two samples were prepared (Blank and of SFB reference standard). The blank was subjected to stress in the same manner as the drug solution. Dry heat and photolytic degradation were carried out in a solid state.

Alkaline Hydrolysis: One $\mathrm{ml}$ working standard solution of SFB $(1000 \mu \mathrm{g} / \mathrm{ml})$ was mixed with $1 \mathrm{ml}$ of $1 \mathrm{~N}$ methanolic $\mathrm{NaOH}$. The solution was kept for $24 \mathrm{~h}$ in a dark place. The resulting solution was neutralised and diluted with methanol to $10 \mathrm{ml} .4$ $\mu 1$ volume of this solution was applied on the TLC plate (400 ng/band). The chromatogram of SFB after alkaline hydrolysis shows $59.79 \%$ recovery, $\mathrm{R}_{\mathrm{f}} 0.45 \& \mathrm{R}_{\mathrm{f}}$ of degradant $0.17 \& 0.26$.

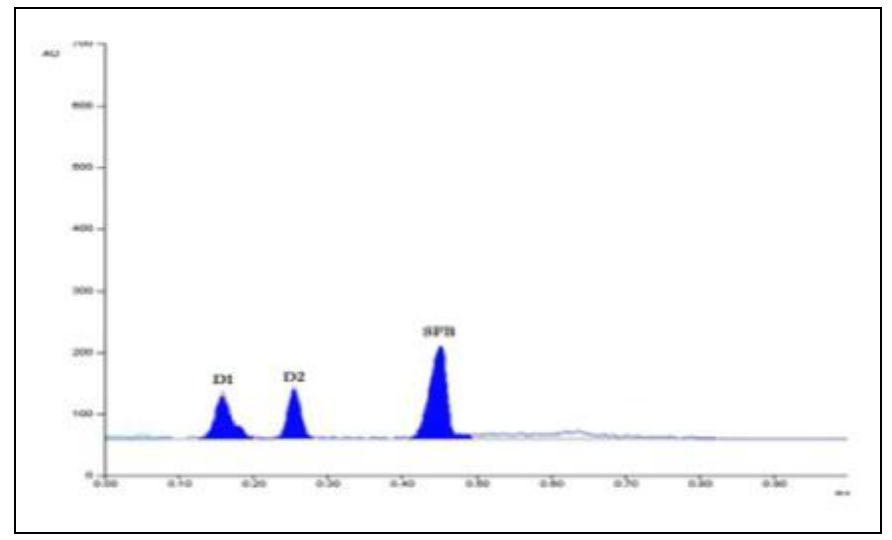

FIG. 2: DENSITOGRAM OF SFB (400 ng/band) AFTER ALKALINE HYDROLYSIS 
Acidic Hydrolysis: One $\mathrm{ml}$ working standard solution of SFB $(1000 \mu \mathrm{g} / \mathrm{ml})$ was mixed with $1 \mathrm{ml}$ of $1 \mathrm{~N}$ methanolic $\mathrm{HCl}$. The solution was kept for $24 \mathrm{~h}$ in a dark place. The resulting solution was neutralised and diluted with methanol to $10 \mathrm{ml}$. 4 $\mu 1$ volume of this solution was applied on the TLC plate (400 $\mathrm{ng} / \mathrm{band}$ ). The chromatogram of SFB after acid degradation shows $91.30 \%$ recovery, $\mathrm{R}_{\mathrm{f}}$ $0.45 \& \mathrm{R}_{\mathrm{f}}$ of degradant 0.26 .

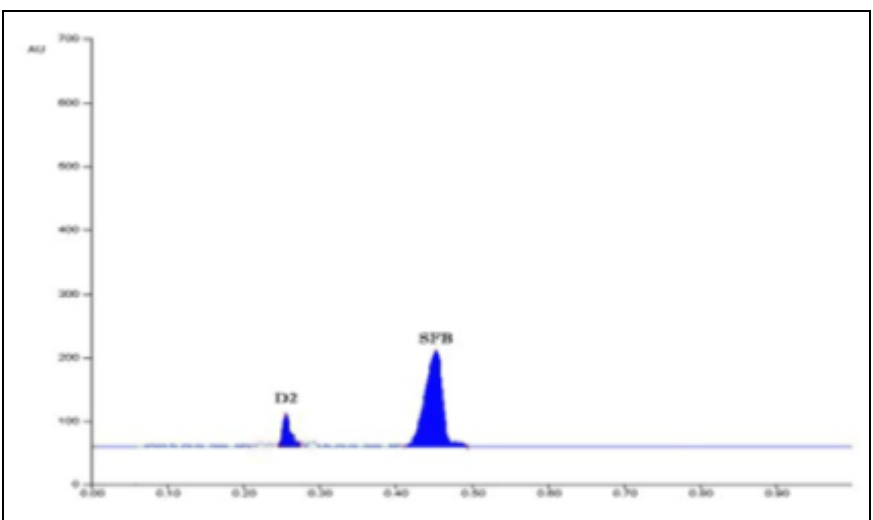

FIG. 3: DENSITOGRAM OF SFB (400 ng/band) AFTER ACID DEGRADATION

Neutral Hydrolysis: One $\mathrm{ml}$ working standard solution of SFB $(1000 \mu \mathrm{g} / \mathrm{ml})$ was mixed with $1 \mathrm{ml}$ of distilled water. The solution was kept for $24 \mathrm{~h}$ in dark place. The resulting solution was diluted with methanol to $10 \mathrm{ml} .4 \mu \mathrm{l}$ volume of this solution was applied on the TLC plate (400 ng/band).

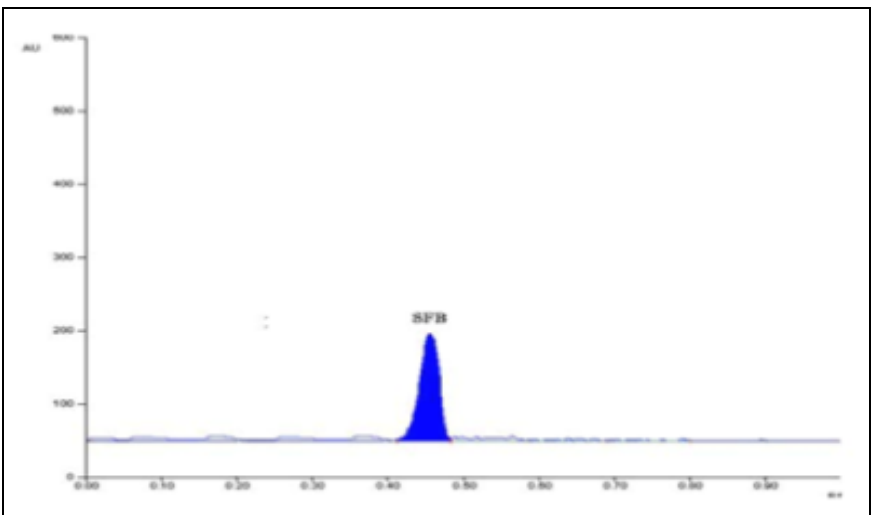

FIG. 4: DENSITOGRAM OF SFB (400 ng/band) AFTER NEUTRAL HYDROLYSIS

Oxidation: One $\mathrm{ml}$ working standard solution of SFB $(1000 \mu \mathrm{g} / \mathrm{ml})$ was mixed with $1 \mathrm{ml}$ of $30 \%$ $\mathrm{H}_{2} \mathrm{O}_{2}$ solution. The solution was kept for $24 \mathrm{~h}$ in a dark place. The resulting solution was diluted with methanol to $10 \mathrm{ml} .4 \mu \mathrm{l}$ volume of this solution was applied on the TLC plate (400 ng/band). The chromatogram of SFB after oxidation shows 94.81 $\%$ recovery, $\mathrm{R}_{\mathrm{f}} 0.45 \& \mathrm{R}_{\mathrm{f}}$ of degradant 0.71 .

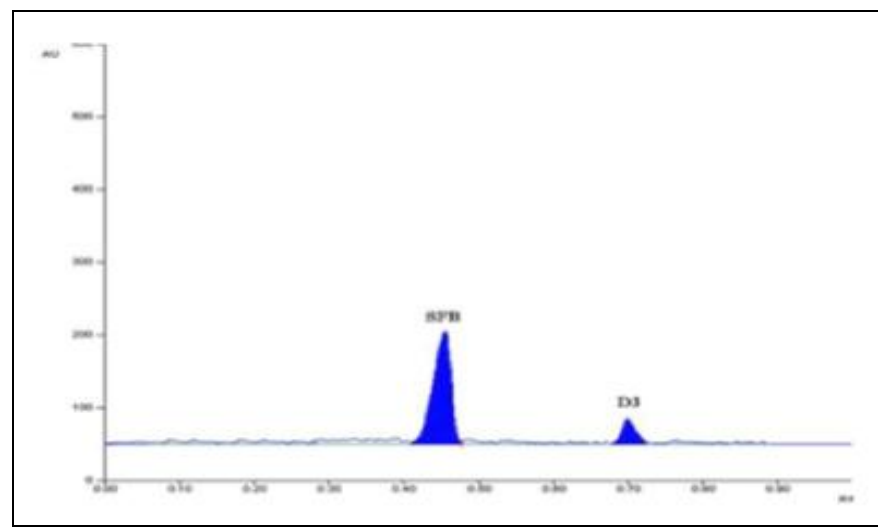

FIG. 5: DENSITOGRAM OF BLANK $\mathrm{H}_{2} \mathrm{O}_{2}$ AND SFB (400 ng/band) AFTER OXIDATION

Degradation under Dry Heat: Dry heat studies were performed by keeping drug sample in oven $\left(80^{\circ} \mathrm{C}\right)$ for a period of $24 \mathrm{~h}$. Sample was withdrawn after $24 \mathrm{~h}$ and processed as per standard solution preparation procedure mentioned under 1.5 to get $100 \mu \mathrm{g} / \mathrm{ml}$ final concentration. $4 \mu \mathrm{l}$ volume of this solution was applied on the TLC plate. (400 ng/band). The chromatogram of SFB after exposing to dry heat shows $100.63 \%$ recovery, $R_{f} 0.45$.

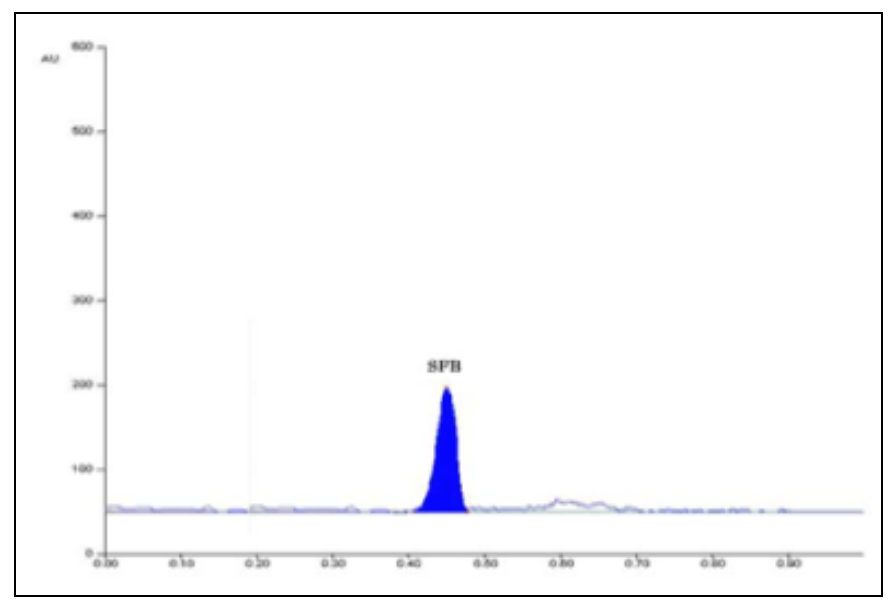

FIG. 6: DENSITOGRAM OF SFB (400 ng/band) AFTER EXPOSING TO DRY HEAT

Photo-Degradation Studies: Photolytic studies were also carried out by exposure of the drug to UV light up to 200 watt-hours/square meter and subsequently to cool fluorescent light to achieve an illumination 1.2 million Lux. Hr.

The sample was withdrawn after exposure and processed as per standard solution preparation procedure mentioned under 1.5 to get $100 \mu \mathrm{g} / \mathrm{ml}$ final concentration. $4 \mu \mathrm{l}$ volume of this solution was applied on the TLC plate (400 ng/band). The chromatogram of SFB after photodegradation shows $99.81 \%$ recovery, $R_{f} 0.45$. 


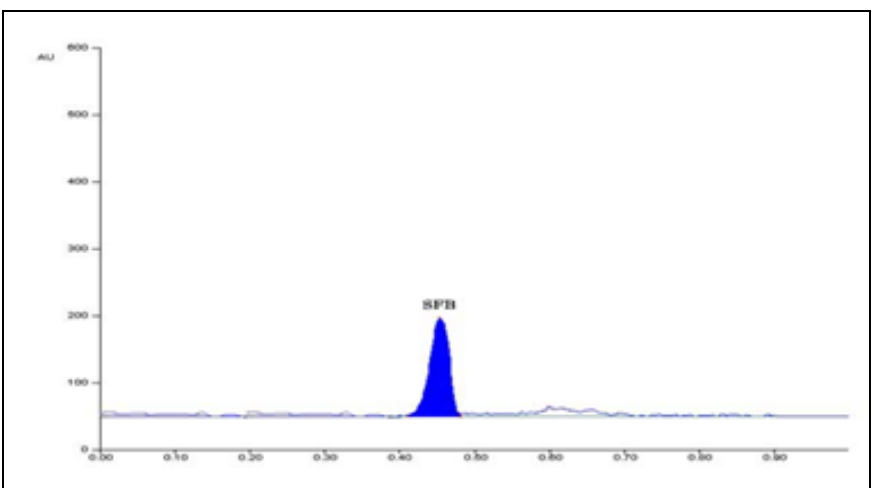

FIG. 7: DENSITOGRAM OF SFB (400 ng/band) AFTER PHOTO DEGRADATION

\section{RESULTS AND DISCUSSION:}

Validation of Analytical Methods:

Linearity and Range: From the standard stock solution $(1000 \mu \mathrm{g} / \mathrm{ml})$ of $\mathrm{SFB}$, further dilutions were made with methanol to get a solution having a concentration of $100 \mu \mathrm{g} / \mathrm{ml}$. Different volumes were applied on TLC plate to obtain a linear range. Six replicates per concentration were applied. The linearity (relationship between peak area and concentration) was determined over the concentration range 100-600 ng/band.

TABLE 1: LINEARITY STUDY OF SFB

\begin{tabular}{|c|c|c|c|c|c|c|}
\hline \multirow{3}{*}{ Replicates } & \multicolumn{6}{|c|}{ Concentrations of SFB } \\
\hline & $100 \mathrm{ng} / \mathrm{band}$ & $200 \mathrm{ng} / \mathrm{band}$ & $300 \mathrm{ng} / \mathrm{band}$ & $400 \mathrm{ng} / \mathrm{band}$ & $500 \mathrm{ng} / \mathrm{band}$ & $600 \mathrm{ng} / \mathrm{band}$ \\
\hline & \multicolumn{6}{|c|}{ Peak Area } \\
\hline 1 & 933.1 & 1844.2 & 2733.1 & 3686.8 & 4625.6 & 5678.9 \\
\hline 2 & 952.1 & 1806.9 & 2730.4 & 3653.2 & 4537.4 & 5581.2 \\
\hline 3 & 922.7 & 1836.2 & 2744.3 & 3666.3 & 4555.6 & 5638.5 \\
\hline 4 & 944.2 & 1825.3 & 2738.2 & 3672.3 & 4566.3 & 5531.5 \\
\hline 5 & 934.5 & 1833.5 & 2736.3 & 3670.2 & 4570.5 & 5655.7 \\
\hline Mean & 937.32 & 1829.22 & 2736.46 & 3669.76 & 4571.08 & 5617.16 \\
\hline Std. Dev. & 11.24 & 14.19 & 5.30 & 12.07 & 33.05 & 59.97 \\
\hline$\%$ RSD & 1.20 & 0.78 & 0.19 & 0.33 & 0.72 & 1.07 \\
\hline
\end{tabular}

Precision: The precision of the method was demonstrated by Intra-day and Inter-day variation studies. In the intraday studies, 3 replicates of 3 different concentrations (200, 400, $600 \mathrm{ng} / \mathrm{band}$ ) of SFB were analyzed in a day, and percentage RSD was calculated. For the inter-day variation studies, 3 replicates of different concentrations were analyzed on 3 consecutive days, and \%RSD was calculated.

TABLE 2: PRECISION STUDY OF SFB

\begin{tabular}{cccccc}
\hline & Intraday Precision & \multicolumn{3}{c}{ Interday Precision } \\
\hline Conc. $(\boldsymbol{\mu g} / \mathbf{m l})$ & \% Recovery & S.D. & Conc. $(\boldsymbol{\mu g} / \mathbf{m l})$ & \% Recovery & S.D. \\
\hline 200 & 101.36 & 1.56 & 200 & 101.33 & 0.62 \\
400 & 99.91 & 0.73 & 400 & 99.16 & 0.46 \\
600 & 100.47 & 1.20 & 600 & 100.23 & 0.64 \\
\hline
\end{tabular}

Accuracy: To check the accuracy of the method, recovery studies were carried out by adding a standard drug to the sample at three different levels 50,100 , and $150 \%$. The basic concentration of the sample chosen was $10 \mu \mathrm{g} / \mathrm{ml}$ of SFB from tablet solution. These solutions were injected in stabilized chromatographic conditions in triplicate to obtain the chromatograms. The drug concentrations of SFB were calculated by using the linearity equation of SFB.

TABLE 3: RECOVERY STUDY OF SFB

\begin{tabular}{|c|c|c|c|c|c|c|}
\hline \multirow[t]{2}{*}{ Level } & \multicolumn{2}{|c|}{ Conc. (ng/band) } & \multirow[t]{2}{*}{ Area } & \multirow[t]{2}{*}{ \% Recovery } & \multirow[t]{2}{*}{ Mean } & \multirow[t]{2}{*}{ \% RSD } \\
\hline & Sample & Std & & & & \\
\hline \multirow[t]{3}{*}{$50 \%$} & 200 & 100 & 2779.7 & 100.648 & 99.266 & 1.330 \\
\hline & & & 2706.3 & 98.017 & & \\
\hline & & & 2737.4 & 99.132 & & \\
\hline \multirow[t]{3}{*}{$100 \%$} & 200 & 200 & 3649.0 & 98.849 & 98.590 & 0.829 \\
\hline & & & 3663.8 & 99.247 & & \\
\hline & & & 3605.3 & 97.674 & & \\
\hline \multirow[t]{3}{*}{$150 \%$} & 200 & 300 & 4611.4 & 99.771 & 99.759 & 0.149 \\
\hline & & & 4617.4 & 99.900 & & \\
\hline & & & 4603.6 & 99.604 & & \\
\hline
\end{tabular}


Limit of Detection (LOD): LOD is calculated from the formula:

$$
\mathrm{LOD}=3.3 \sigma / \mathrm{S}=8.009 \mathrm{ng} / \mathrm{band}
$$

Where, $\sigma=$ standard deviation of response for the lowest conc. in the range, $S=$ slope of the calibration curve.

Limit of Quantification (LOQ): The quantitation limit is expressed as:

$$
\mathrm{LOD}=10 \sigma / \mathrm{S}=24.270 \mathrm{ng} / \mathrm{band}
$$

Where, $\sigma=$ standard deviation of response for the lowest conc. in the range, $S=$ slope of the calibration curve.

Robustness: The robustness of the method was determined by carrying out the analysis under conditions during which chamber saturation time, time form application to development, and time form development to scanning are altered, and the effect on the area was noted.

\begin{tabular}{|c|c|c|c|c|c|c|c|c|c|}
\hline \multirow[t]{2}{*}{ Drug } & \multicolumn{9}{|c|}{ \% RSD Found For Robustness Study } \\
\hline & \multicolumn{3}{|c|}{$\begin{array}{l}\text { Mobile phase saturation time } \\
( \pm 10 \%) \mathrm{min}\end{array}$} & \multicolumn{3}{|c|}{$\begin{array}{c}\text { Time from application to } \\
\text { development (min) }\end{array}$} & \multicolumn{3}{|c|}{$\begin{array}{c}\text { Time from development to } \\
\text { scanning (min) }\end{array}$} \\
\hline SFB & $\begin{array}{c}13.5 \\
0.808\end{array}$ & $\begin{array}{c}15 \\
0.622 \\
\end{array}$ & $\begin{array}{c}16.5 \\
0.979\end{array}$ & $\begin{array}{c}10 \\
0.870\end{array}$ & $\begin{array}{c}20 \\
1.737 \\
\end{array}$ & $\begin{array}{c}30 \\
0.890 \\
\end{array}$ & $\begin{array}{c}30 \\
1.355 \\
\end{array}$ & $\begin{array}{c}60 \\
1.360 \\
\end{array}$ & $\begin{array}{c}90 \\
1.498 \\
\end{array}$ \\
\hline
\end{tabular}

TABLE 4: ROBUSTNESS STUDY OF SFB

DISCUSSION: Stability indicating HPTLC method for the determination of SFB was developed. Linearity for SFB was found in the range of 100-600 $\mathrm{ng} / \mathrm{band}$ with a regression coefficient $\left(\mathrm{R}^{2}\right)$ of 0.999 , it indicates that the proposed method is found to be linear. LOD and LOQ values were $8.009 \mathrm{ng} / \mathrm{b}$ and and $24.27 \mathrm{ng} / \mathrm{band}$, respectively. The RSD values for intraday and interday precision studies were found to be less than $2 \%$. This low value of RSD indicates that the proposed method is precise. Degradation of SFB was found to occur under acidic condition (1N $\mathrm{HCl}, 24 \mathrm{~h})$, alkaline condition (1N NaOH, $24 \mathrm{~h})$, and oxidative condition $\left(30 \% \mathrm{H}_{2} \mathrm{O}_{2}, 24 \mathrm{~h}\right)$, SFB was considerably stable in neutral $(24 \mathrm{~h})$, dry heat $\left(80{ }^{\circ} \mathrm{C}\right.$ for $24 \mathrm{~h}$ ) and photostability [UV, 200-watt hrs/square meter Florescence, 1.2 million Lux. hrs].

\section{SUMMARY:}

TABLE 5: SUMMARY OF STRESS DEGRADATION STUDY OF SFB RS

\begin{tabular}{cccccc}
\hline S. no. & Stress Conditions & \% Recovered for SFB (\%) & $\mathbf{R}_{\mathbf{f}}$ of SFB & \% Degradation & $\mathbf{R}_{\mathbf{f}}$ of Degradant \\
\hline 1 & Base (1 N NaOH, kept for 2 hr) & 59.79 & 0.45 & 40.21 & $0.17,0.26$ \\
2 & Acid (1 N HCl, Kept for 24 hr) & 91.30 & 0.45 & 0.70 & -- \\
3 & Neutral (kept for 24 hr) & 98.83 & 0.46 & 5.19 & -- \\
4 & $\mathrm{H}_{2} \mathrm{O}_{2}, 30 \%$ (kept for 24 hr) & 94.81 & 0.45 & -- & -- \\
5 & Dry Heat (80 C for 24 hr.) & 99.96 & 0.45 & -- \\
6 & Photo stability [UV, 200 watt & 99.81 & & \\
& hrs/square meter Florescence, 1.2 & & & \\
& million Lux. Hrs] & & & \\
\hline
\end{tabular}

TABLE 6: SUMMARY OF VALIDATION STUDY

\begin{tabular}{ccc}
\hline $\begin{array}{c}\text { S. } \\
\text { no. }\end{array}$ & Validation Parameter & $\begin{array}{c}\text { Results } \\
\text { SFB }\end{array}$ \\
\hline 1. & Linearity Equation & $\mathrm{y}=9.302 \mathrm{x}-28.97$ \\
2. & Range & $100-600 \mathrm{ng} / \mathrm{band}$ \\
3. & Assay (Mean $\pm \%$ RSD) & $100.46 \pm 1.04$ \\
& Precision & Mean $\pm \% \mathrm{RSD}$ \\
4. & Intraday precision & $100.584 \pm 0.724$ \\
& Interday precision & $100.245 \pm 1.084$ \\
& Accuracy & Mean $\pm \% \mathrm{RSD}$ \\
5. & $50 \%$ & $99.266 \pm 1.330$ \\
& $100 \%$ & $98.590 \pm 0.829$ \\
6. & $150 \%$ & $99.759 \pm 0.149$ \\
7. & LOD & $8.009 \mathrm{ng} / \mathrm{band}$ \\
& LOQ & $24.270 \mathrm{ng} / \mathrm{band}$ \\
\hline
\end{tabular}

CONCLUSION: In the present work, stabilityindicating HPTLC methods for the estimation of SFBwere developed and validated as per ICH guidelines. The standard deviation and \% RSD $(<2$ $\%)$ is within the limit, indicating a high degree of precision of the methods.

The results of the recovery studies performed show the high degree of accuracy of the proposed methods. Hence, it can be concluded that the developed methods are simple, accurate and precise, reproducible, and economical. 
ACKNOWLEDGEMENT: The work was carried out by Amoldeep Shinde, under the guidance of Dr. Mrs. Minal Ghante and Dr. Sanjay Sawant. Dr. Vidhya Bhusari has contributed to writing the manuscript and proofreading the same.

CONFLICTS OF INTEREST: The authors do not have any conflict of interest.

\section{REFERENCES:}

1. Singh H: Sofosbuvir: A novel treatment option for chronic hepatitis C infection. Journal of pharmacology and pharmaco-therapeutics 2014; 5: 278-84.

2. Lawitz E, Mangia A, Wyles D and Rodriguez-Torres M: Sofosbuvir for previously untreated chronic hepatitis C infection.The New England Journal of Medicine 2013; 368: 1878-87.

3. Devilal J, Durgaprasad B, Pal N and Avanapu SR: New method development and validation for the determination of Ledipasvir in bulk drug form by using reverse phase HPLC technique. World Journal of Pharmacy and Pharmaceutical Sciences 2016; 5: 1312-21.

4. El-Kassem M and Hassouna1 M: Assay and dissolution methods development and validation for simultaneous determination of Sofosbuvir and Ledipasvir by RP-HPLC Method in Tablet Dosage Forms. Journal of Forensic Sciences \& Criminal Investigation 2017; 1: 001-0011.

5. Zaman B and Siddique F: RP HPLC Method for simultaneous determination of Sofosbuvir and Ledipasvir in tablet dosage form and its application to in vitro dissolution studies. Chromatographia 2017; 79: 1605-13.

6. Singh K, Bhatt S and Prasad: HPLC method for estimation of drug release of Sofosbuvir in pharmaceutical formulation. International Journal of Pharmaceutical Sciences and Research 2019; 10: 367-72.

7. Yasir M, Khan IU, Shahzad Y, Khalid SH, Irfan M, Asghar S, Yousaf AM, Hussain $\mathrm{T}$ and Khalid I: Development and validation of a stability-Indicating RPHPLC method for simultaneous estimation of sofosbuvir and velpatasvir in fixed dose combination tablets and plasma. Pak J Pharm Sci 2019; 32: 1835-42.

8. Semreen MH, Alniss HY, Mousa MK and Aboul-Enein HY: Quick and sensitive UPLC-ESI-MS/MS method for simultaneous estimation of Sofosbuvir and its metabolite in human plasma. Molecule 2019; 24: 1302.

9. Rezk MR, Basalious EB and Karim IA: Development of a sensitive UPLC-ESI-MS/MS method for quantification of Sofosbuvir and its metabolite, GS-331007, in human plasma: Application to a bioequivalence study. J Pharm Biomed Anal 2015; 114: 97-104.

10. ICH Q1A(R2), Stability testing of New Drug Substances and Products, in: Proceedings of the International Conference on Harmonization, Geneva, August 2003.

11. ICH Q2A, Harmonised Tripartite Guideline, Text on Validation of Analytical Procedures: Text and Methodology, in: Proceedings of the International Conference on Harmonization, Geneva, October 1994.

12. ICH, Q2B, Harmonised Tripartite Guideline, Validation of Analytical Procedure: Methodology, in: Proceedings of the International Conference on Harmonization, Geneva, November 1996.

How to cite this article:

Ghante MR, Sawant SD, Shinde A and Bhusari VK: Development and validation of stability indicating HPTLC method for the estimation of sofosbuvir. Int J Pharm Sci \& Res 2021; 12(5): 2656-61. doi: 10.13040/IJPSR.0975-8232.12(5).2656-61.

All @ 2013 are reserved by the International Journal of Pharmaceutical Sciences and Research. This Journal licensed under a Creative Commons Attribution-NonCommercial-ShareAlike 3.0 Unported License.

This article can be downloaded to Android OS based mobile. Scan QR Code using Code/Bar Scanner from your mobile. (Scanners are available on Google Playstore) 